\title{
Medium Optimization for Bacteriocin Production and Bacterial Cell Growth of Geobacillus sp. 15 Strain
}

Kaunietis A*, Pranckutè R, Lastauskienè E and Čitavičius DJ

Life Sciences Center, Vilniaus University, Vilnius, Lithuania

“Corresponding author: Kaunietis A, Life Sciences Center, Vilniaus Universitetas, Vilnius, Lithuania, Tel: 37068531352; E-mail: kavenis1@gmail.com

Received date: January 21, 2017; Accepted date: January 31, 2017; Published date: February 7, 2017

Copyright: (C) 2017 Kaunietis A, et al. This is an open-access article distributed under the terms of the Creative Commons Attribution License, which permits unrestricted use, distribution, and reproduction in any medium, provided the original author and source are credited.

\begin{abstract}
In this study we determined that Geobacillus sp. 15 strain secretes antibacterial compound-bacteriocin. Only few bacteriocin producing thermophilic bacteria of this genus have been identified to the date. Also, we optimized medium composition for the better cell growth of this strain and increased the yield of secreted bacteriocin. In this work we showed that some particular salts or their combinations may have impact on higher growth of Geobacillus sp. 15 strain bacteria or their produced bacteriocins. These results can facilitate research on this strain and its secreted bacteriocin. These antibacterial proteins and peptides are promising natural agents as an alternative to antibiotics in medicine or veterinary and to traditional preservatives in food industry. Optimized composition of the growth medium can be very useful for studies of other Geobacillus spp. strains and their produced bacteriocins. Furthermore, these data may be used to increase the biomass of Geobacillus bacteria and the yield of protein when it is dependent on bacterial cell yield.
\end{abstract}

Keywords Geobacillus sp; Bacteriocin; Medium; Optimization; Salts

\section{Introduction}

Geobacillus bacteria are rod-shaped Gram-positive, aerobic and spore-forming thermophiles. They are frequently isolated from hot environments like hot springs, oil wells, compost or desert soils. Most isolates grow in temperatures between about $45^{\circ} \mathrm{C}$ and $70^{\circ} \mathrm{C}$, with optima between $50^{\circ} \mathrm{C}$ and $60^{\circ} \mathrm{C}$. They are neutrophilic and grow within a relatively narrow $\mathrm{pH}$ between 5.0 and 9.0, and their optima lie within the range $\mathrm{pH}$ 6.2-7.5. Most strains will grow on routine media such as nutrient agar. For the species tested, growth factors, vitamins, $\mathrm{NaCl}$, and $\mathrm{KCl}$ are not required. A wide range of substrates is utilized, including carbohydrates, organic acids, peptone, tryptone, and yeast extract; the ability to utilize hydrocarbons as carbon and energy sources is a widely distributed property in the genus $[1,2]$.

Geobacillus spp. are attractive to the biotechnology industry as source of thermostable enzymes and natural products digesters of lignocellulose, bioremediators of hydrocarbons or as platforms for biofuel production [2,3]. Some Geobacillus spp. strains produce bacteriocins. It is ribosomally synthesised antimicrobial peptides secreted by various bacteria. They can be active against human and animal microbial pathogens, including methicillin-resistant Staphylococcus aureus (MRSA) and vancomycin-resistant enterococci (VRE) without showing toxicity. The advantages of bacteriocins are their physical stability and non-toxicity. Numerous bacteriocins have great potential as food preservatives or as therapeutic or biocontrolling agents [4-6].

To date, only few bacteriocin producing thermophilic bacterial strains of genus Geobacillus have been identified: $G$. stearothermophilus [7], G. toebii strain HBB-218 [8], G. toebii strain HBB-247 [9], G. thermodenitrificans [10] and in Geobacillus sp. strain ZGt-1 [11]. Studies of factors affecting the production of bacteriocins by Geobacillus spp. are relatively scarce.
The growth of bacteria and accumulation of their metabolites are strongly influenced by growth environment and medium composition $[12,13]$. The effects of medium composition for bacteriocin production have been studied for pediocin AcH [14], pediocin PD-1 [15], enterocin P [16], nisin [17], plantaricin 423 [18], and sakP [19]. Bacteriocin production may be strongly influenced by carbon sources, nitrogen sources, inorganic salts, temperature and $\mathrm{pH}$ [20-23]. Bacteriocin production is usually growth associated, i.e. the level at which the peptide is produced is linked to the biomass formed [19,24-27]. Some studies have indicated that bacteriocin production and activity levels do not always correlate with cell mass or growth rate of the producer strain $[26,28]$. Higher bacteriocin levels are often obtained at temperatures, nutrient sources and $\mathrm{pH}$ values lower than required for optimal growth [19,24,25,29-32].

It suggests that low growth rate, unfavourable growth conditions or other less optimal environmental conditions may also stimulate bacteriocin production $[19,25,27]$. Our lab experience with Geobacillus bacteria shows that some of the strains exhibit poor growth and sometimes it is hard to select appropriate medium for good growth. It complicates research on these bacteria and their produced compounds like bacteriocins. These reasons prompt us to optimize the growth medium for Geobacillus sp. 15 strain which produce antibacterial small proteins-bacteriocins. The aim of the present study was to optimize medium composition for a better cell growth of Geobacillus $s p .15$ strain and for higher yield of the secreted bacteriocin in constituted growth media.

\section{Materials and Methods}

\section{Strains used in this work}

Geobacillus sp. 15 strain was previously isolated from oil well in Lithuania and was used as a bacteriocin producer in this work. Geobacillus stearothermophilus NUB36187 (BGSC No. 9A11) was selected as indicator strain for bacteriocin activity assays. 


\section{Strain identification}

Genomic DNA of Geobacillus sp. 15 strain was extracted. Polymerase chain reaction (PCR) was used to amplify DNA of $16 \mathrm{~S}$ rRNA coding region. Following PCR primers were used in this reaction: 27F (5' GAG AGT TTG ATC CTG GCT CAG 3') and 1495R (5' CTA CGG CTA CCT TGT TAC GA 3'). DNA amplicon of $16 \mathrm{~S}$ rRNA region was sequenced and the sequence was examined by comparing it with other sequences in database of DNA (http:// blast.ncbi.nlm.nih.gov/Blast.cgi).

\section{Growth media}

Nutrient broth (NB) medium containing $10 \mathrm{~g} / \mathrm{l}$ peptone from casein $5 \mathrm{~g} / \mathrm{l}$ meat extract and $5 \mathrm{~g} / \mathrm{l}$ sodium chloride was used in this work. NB medium supplemented with $20 \%$ (v/w) glycerol was separately used for stock cultures stored in $-70^{\circ} \mathrm{C}$. Prior to use bacterial cultures in liquid media strains were cultivated on solid medium (NB supplemented with $1.5 \% \mathrm{v} / \mathrm{w}$ of agar). Liquid medium of $\mathrm{NB}$ was supplemented with following salts: KCl-0.07 $\mu \mathrm{mol} / \mathrm{l}, \mathrm{ZnSO}_{4}-0.91 \mu \mathrm{mol} / \mathrm{l}, \mathrm{MnSO}_{4}-0.47$ $\mu \mathrm{mol} / \mathrm{l}, \quad \mathrm{CuSO}_{4}-0.6 \mu \mathrm{mol} / \mathrm{l}, \quad \mathrm{MgCl}_{2}-1.1 \mu \mathrm{mol} / \mathrm{l}, \quad \mathrm{CaCl}_{2}-2.3 \mu \mathrm{mol} / \mathrm{l}$, $\mathrm{NaNO}_{3}-0.5 \mu \mathrm{mol} / \mathrm{l}, \mathrm{NaHCO}_{3}-\mu \mathrm{mol} / \mathrm{l}$ in various variations (Table 1 ) for medium optimization experiments.

\begin{tabular}{|c|c|c|}
\hline Additives & $\begin{array}{l}\text { Max } \\
\text { OD }\end{array}$ & $\operatorname{Max} \mathrm{AU} / \mathrm{ml}$ \\
\hline Basic medium & 3.2 & 40 \\
\hline $\begin{array}{l}\mathrm{CuSO}_{4}, \mathrm{NaHCO}_{3}, \mathrm{NaNO}_{3}, \mathrm{MnSO}_{4}, \mathrm{KCl}, \mathrm{CaCl}_{2}, \mathrm{MgCl}_{2} \text {, } \\
\mathrm{ZnSO}_{4}\end{array}$ & 4.32 & 160 \\
\hline $\mathrm{CuSO}_{4}, \mathrm{NaHCO}_{3}, \mathrm{NaNO}_{3}, \mathrm{MnSO}_{4}$ & 0.62 & 80 \\
\hline $\mathrm{KCl}, \mathrm{CaCl}_{2}, \mathrm{MgCl}_{2}, \mathrm{ZnSO}_{4}$ & 3.2 & 160 \\
\hline $\mathrm{KCl}, \mathrm{MgCl}_{2}$ & 4.36 & 320 \\
\hline $\mathrm{CaCl}_{2}, \mathrm{ZnSO}_{4}$ & 2.76 & 320 \\
\hline $\mathrm{CuSO}_{4}, \mathrm{NaNO}_{3}$ & 2.48 & 80 \\
\hline $\mathrm{MnSO}_{4}, \mathrm{NaHCO}_{3}$ & 4.54 & 320 \\
\hline $\mathrm{KCl}$ & 2.88 & 160 \\
\hline $\mathrm{MgCl}_{2}$ & 3.76 & 160 \\
\hline $\mathrm{CaCl}_{2}$ & 2.92 & 80 \\
\hline $\mathrm{ZnSO}_{4}$ & 2.48 & 80 \\
\hline $\mathrm{NaNO}_{3}$ & 2.88 & 40 \\
\hline $\mathrm{MnSO}_{4}$ & 5.44 & 160 \\
\hline $\mathrm{CuSO}_{4}$ & 2.88 & 40 \\
\hline $\mathrm{NaHCO}_{3}$ & 2.56 & 80 \\
\hline
\end{tabular}

Table 1: Additives, the highest bacteriocin activity (Max AU/ml) and the highest optical density (Max OD) during the growth.

These particular salts were chosen based on observations in our laboratory that Geobacillus spp. strains maintained better growth and bacteriocin production in NB medium that was prepared with a tap water. All previous salts and their concentrations used in this work were equivalent to the salts and their molarities that were found in the tap water of our laboratory. All media's components and chemicals were purchased from Merck.

\section{Cultivation Conditions}

$50 \mathrm{ml}$ of sterile NB medium was inoculated with of Geobacillus $s p$. 15 strain to the final optical density (OD) 0.06 measuring at $595 \mathrm{~nm}$ wavelength in $1 \mathrm{~cm}$ diameter cuvette. The $\mathrm{pH}$ of growth medium before use was adjusted to 6.85 with $5 \mathrm{M} \mathrm{NaOH}$ (Barta a Cihlar, spol. s. r. o.). Inoculated medium was cultivated for 12 hours at $55^{\circ} \mathrm{C}, 200 \mathrm{rpm}$. Every hour samples of bacterial culture were taken to measure OD and bacteriocin activity using agar well diffusion assay.

\section{Selection of Bacteriocin Producing Strain}

Melted NB medium supplemented with $1.5 \%$ agar was cooled down to $55^{\circ} \mathrm{C}$ and inoculated with the sensitive strain Geobacillus stearothermophilus to the final OD 0.32 measuring at $595 \mathrm{~nm}$ wavelength in $1 \mathrm{~cm}$ diameter cuvette. Inoculated medium was poured in a Petri plate. When the medium was solid bacteriocin producer strain Geobacillus $s p$. 15 was seeded in the center of the plate which was later incubated in a thermostat for 16 hour at $55^{\circ} \mathrm{C}$. After that inhibition zone around the producer strain was inspected.

\section{Agar Well Diffusion Assay}

Melted NB medium supplemented with $1.5 \%$ agar was cooled down to $55^{\circ} \mathrm{C}$ and inoculated with bacteriocin sensitive strain Geobacillus stearothermophilus to the final OD 0.32 measuring at $595 \mathrm{~nm}$ wavelength in $1 \mathrm{~cm}$ diameter cuvette. Inoculated medium was poured in a Petri plates. When the medium was solid $1 \mathrm{~cm}$ diameter wells were cut in it. Samples of bacterial culture were centrifuged at $10000 \mathrm{x} g$ and supernatants were collected. Serial twofold dilutions of supernatant were made with buffer tris- $\mathrm{HCl}, 50 \mathrm{mM}, \mathrm{pH}$ 7.5. $100 \mu \mathrm{l}$ of diluted supernatant samples were poured into the wells and incubated for 16 hour at $55^{\circ} \mathrm{C}$. After that inhibition zones around the wells were inspected to determine antibacterial activity of bacteriocin which is expressed in arbitrary units $(\mathrm{AU})$ per $\mathrm{ml}$. $\mathrm{AU} / \mathrm{ml}=(1 \mathrm{ml} \times \mathrm{V}-1) / \mathrm{D}-1$, $\mathrm{V}$ sample volume $(\mathrm{ml}), \mathrm{D}$-the reciprocal of the highest dilution showing a clear zone of growth inhibition around the well.

\section{Bacteriocin Extraction and its Treatment With proteinase $\mathrm{K}$}

Geobacillus sp. 15 strain was grown in NB medium and when cells reached stationary phase the medium with bacteria was centrifuged at $10000 \times$ G for $15 \mathrm{~min}$ at $+4^{\circ} \mathrm{C}$ temperature. Supernatant was collected and saturated with ammonium sulphate up to $80 \%$. Then it was centrifuged at $15000 \times \mathrm{G}$ for $30 \mathrm{~min}$ at $+4^{\circ} \mathrm{C}$ temperature. Protein pallets were collected, dissolved in $50 \mathrm{mM}$ tris- $\mathrm{HCl}$ (Sigma-Aldrich) $\mathrm{pH} 7.5$ buffer and desalted in SnakeSkin 3.5 MWCO dialysis tubing (Thermo Scientific) which was immersed in the same buffer. Latter on this dialyzed crude protein extract (CPE) was treated with proteinase $\mathrm{K}$ (Sigma-Aldrich) enzyme. $100 \mu \mathrm{L}$ of CPE mixed with $100 \mu \mathrm{L}$ proteinase $\mathrm{K}(1 \mathrm{mg} / \mathrm{ml}$ in $50 \mathrm{mM}$ tris- $\mathrm{HCl} \mathrm{pH}$ 7.5) solution. For control experiment $100 \mu \mathrm{l}$ of $50 \mathrm{mM}$ tris- $\mathrm{HCl} \mathrm{pH} 7.5$ buffer was used instead of proteinase $\mathrm{K}$ solution. Mixtures incubated in $37^{\circ} \mathrm{C}$ temperature for 1 hour and then antibacterial activity was tested using agar well diffusion assay. 
Citation: Kaunietis A, Pranckute R, Lastauskiene E, Citavicius DJ (2017) Medium Optimization for Bacteriocin Production and Bacterial Cell Growth of Geobacillus sp. 15 Strain. J Antimicrob Agents 3: 133. doi:10.4172/2472-1212.1000133

Page 3 of 5

\section{Results}

\section{Bacteriocin producer strain selection and its identification}

Bacteriocin producing strain selection showed that Geobacillus sp. 15 strain secretes antibacterial substance that inhibits growth of Geobacillus stearothermophilus (Figure 1) and it was selected for further work in this study. DNA sequence coding $16 \mathrm{~S}$ rRNA of strain 15 analysis showed 99\% homology to Geobacillus stearothermophilus 16 rRNA coding sequence. Because of that bacteriocin producer strain were defined as Geobacillus stearothermophilus 15 strain and it is closely related to the sensitive strain.



Figure 1: Geobacillus sp. 15 strain antibacterial activity against Geobacillus sp. 9A11 strain.

\section{Bacteriocin extraction and its treatment with proteinase $K$}

CPE treated with proteinase $\mathrm{K}$ had decreased antibacterial activity against sensitive strain G. stearothermophilus (Figure 2). These results indicated that antibacterial activity is associated with protein or peptide.



Figure 2: Antibacterial activity of CPE, (a)-not treated with proteinase $\mathrm{K}$, (b)-treated with proteinase $\mathrm{K}$.

\section{Growth Medium Optimization for Higher Cell Growth and Bacteriocin Production}

Bacterial strain 15 was grown in NB media supplemented with various variations of salts (Table 1). During the growth samples of bacterial culture were collected for OD determination and bacteriocin activity assays. Based on OD measurements growth curves were generated for all tested media which were supplemented with salts and compared to the control-growth in the medium without any salts added (Figure 4).

Testing every salt separately it was revealed that in the most cases the growth was reduced and only in the medium supplemented with $\mathrm{MgCl}_{2}$ or $\mathrm{MnSO}_{4}$ the cell growth was increased and higher OD was reached (Figure $4 \mathrm{c}$ and $4 \mathrm{~d}$ ).

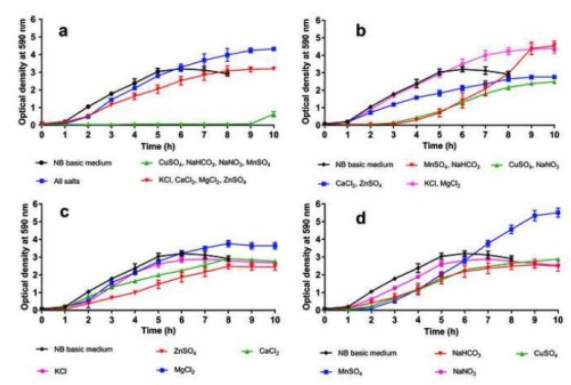

Figure 4: Geobacillus sp. 15 strain growth in the basic and modified media.

The growth in the media supplemented combining $\mathrm{CuSO}_{4}$ and $\mathrm{NaNO}_{3}$ or $\mathrm{CaCl}_{2}$ and $\mathrm{ZnSO}_{4}$ was decreased compared to that in the control NB medium without salts (Figure 3b). Meanwhile combining $\mathrm{CuSO}_{4}, \mathrm{NaHCO}_{3}, \mathrm{NaNO}_{3}$ and $\mathrm{MnSO}_{4}$ the growth was practically inhibited (Figure 3a).

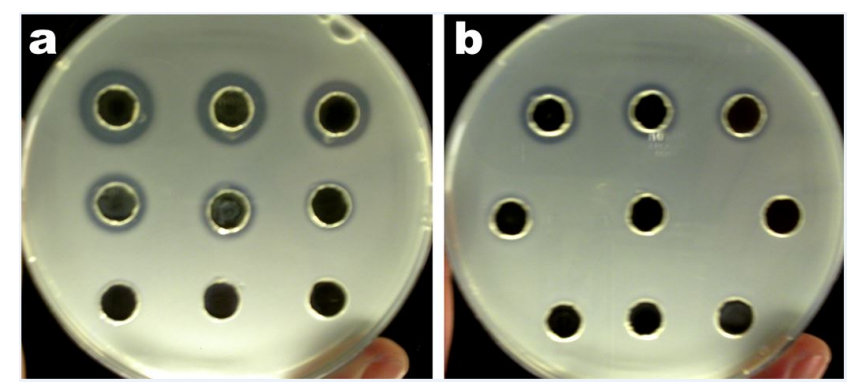

Figure 3: Geobacillus sp. 15 strain produced bacteriocin activity in supernatant: (a)-modified medium supplemented with $\mathrm{KCl}$ and $\mathrm{MgCl}_{2}$; (b)-basic medium.

Combining all 8 tested salts or combinations of $\mathrm{KCl}$ and $\mathrm{MgCl}_{2}$ or $\mathrm{MnSO}_{4}$ and $\mathrm{NaHCO}_{3}$ revealed higher cell growth and OD. Besides the growth in these media bacteriocin activities were also evaluated every hour. The highest activities observed during the growth in every modified media were compared between different media. In the control media where salts were not added the highest bacteriocin activity during the growth was determined $40 \mathrm{AU} / \mathrm{ml}$. In the media where every salt was tested separately, the best results were achieved with $\mathrm{KCl}, \mathrm{MgCl}_{2}$ or $\mathrm{MnSO}_{4}$, the activity in supernatant during the growth was increased up to $160 \mathrm{AU} / \mathrm{ml}$. The same results were observed in the medium that was supplemented with all 8 salts or in 
the medium supplemented with combining $\mathrm{KCl}, \mathrm{CaCl}_{2}, \mathrm{MgCl}_{2}$ and $\mathrm{ZnSO}_{4}$.

After testing all salts and combinations of it in this work, the highest bacteriocin activity was achieved in media supplemented combining $\mathrm{KCl}$ and $\mathrm{MgCl}_{2}$ or $\mathrm{CaCl}_{2}$ and $\mathrm{ZnSO}_{4}$ or $\mathrm{MnSO}_{4}$ and $\mathrm{NaHCO}_{3}$. In this case the highest activity during the growth in these modified media was increased up to $320 \mathrm{AU} / \mathrm{ml}$. All the rest medium variants did not increase or increased bacteriocin activity up to $80 \mathrm{AU} / \mathrm{ml}$.

\section{Discussion}

Based on 16S rRNA sequence homology analysis it was revealed that 15 strain isolate may be defined to Geobacillus stearothermophilus species. Bacteriocin producer strain selection and agar well diffusion assay showed that this strain secretes antibacterial substance that can inhibit growth of closely related bacteria Geobacillus stearothermophilus NUB36187. Protein extraction from the supernatant and CPE treatment with protease results indicates that 15 strain secretes to the medium antibacterial compound-bacteriocin.

In this study growth conditions were determined for higher Geobacillus stearothermophilus 15 strain yield. Growth media optimization experiments showed that Geobacillus stearothermophilus strain 15 growth can be enhanced by $\mathrm{MgCl}_{2}$. Combination of $\mathrm{MgCl}_{2}$ with $\mathrm{KCl}$ can be even better that using $\mathrm{MgCl}_{2}$ only. The best growth was achieved in $\mathrm{NB}$ medium supplemented only with $\mathrm{MnSO}_{4}$. Growth media components were identified that may increase better bacteriocin production in Geobacillus stearothermophilus 15 strain. Evaluation of bacteriocin activity in media supplemented with every salt separately shows that activity may be enhanced using $\mathrm{KCl}, \mathrm{MgCl}_{2}$ or $\mathrm{MnSO}_{4}$. The best results can be achieved combining two salts: $\mathrm{KCl}$ and $\mathrm{MgCl}_{2}$, $\mathrm{CaCl}_{2}$ and $\mathrm{ZnSO}_{4}$ or $\mathrm{MnSO}_{4}$ and $\mathrm{NaHCO}_{3}$.

Results show that some particular salts or combinations may have impact on higher growth of bacteria but it not always has relation to higher bacteriocin activity in the supernatant. Conclusion may be done that bacteriocin secretion does not depend on better growth of bacterial culture. Determined salts for better bacterial growth and higher bacteriocin production will facilitate investigations of this strain and its secreted bacteriocin. These results may be very useful for studies of other Geobacillus spp. strains and their produced bacteriocins. Furthermore, these data may be used to increase the biomass and the yield of protein when it is dependent on bacterial cell yield.

\section{Acknowledgement}

This work was done and supported by department of Microbiology and Biotechnology of Vilnius University.

\section{References}

1. Nazina T, Tourova T, Poltaraus A, Novikova E, Grigoryan A, et al. (2001) Taxonomic study of aerobic thermophilic bacilli: descriptions of Geobacillus subterraneus gen. nov., sp. nov. and Geobacillus uzenensis sp. nov. from petroleum reservoirs and transfer of Bacillus stearothermophilus, Bacillus thermocatenulatus, Bacillus thermoleovorans, Bacillus kaustophilus, Bacillus thermoglucosidasius and Bacillus thermodenitrificans to Geobacillus as the new combinations G. stearothermophilus, G. thermocatenulatus, G. thermoleovorans, G. kaustophilus, G. thermoglucosidasius and G. thermodenitrificans. Int J Syst Evol Microbiol 51: 433-446.
2. Hussein AH, Lisowska BK, Leak DJ (2015) The genus Geobacillus and their biotechnological potential. Adv Appl Microbiol 92: 1-48.

3. Studholme DJ (2015) Some (bacilli) like it hot: genomics of Geobacillus species. Microb Biotechnol 8: 40-48.

4. Lohans CT, Vederas JC (2012) Development of class IIa bacteriocins as therapeutic agents. Int J Microbiol: 1-3.

5. Bali V, Panesar PS, Bera MB, Kennedy JF (2014) Bacteriocins: Recent Trends and Potential Applications. Crit Rev Food Sci Nutr 56: 817-834.

6. Ahmad V, Khan MS, Jamal QM, Alzohairy MA, Al Karaawi MA, et al. (2017) Antimicrobial potential of bacteriocins: in therapy, agriculture and food preservation. Int J Antimicrob Agents 49: 1-11.

7. Pokusaeva K, Kuisiene N, Jasinskyte D, Rutiene K, Saleikiene J, et al. (2009) Novel bacteriocins produced by Geobacillus stearothermophilus. Cent Eur J Biol 4: 196-203.

8. Ozdemir GB, Biyik HH (2011) Isolation and characterization of toebicin 218, a bacteriocin, produced by Geobacillus toebii HBB-218. Afr J Biotechnol 11: 7711-7719.

9. Ozdemir GB, Biyik HH (2012) Isolation and characterization of a bacteriocin-like substance produced by Geobacillus toebii strain HBB-247. Indian J Med Microbiol 52: 104-108.

10. Garg N, Tang W, Goto Y, Nair SK, van der Donk WA (2012) Lantibiotics from Geobacillus thermodenitrificans. PNAS 109: 5241-5246.

11. Alkhalili RN, Bernfur K, Dishisha T, Mamo G, Schelin J, et al. (2016) Antimicrobial Protein Candidates from the Thermophilic Geobacillus sp. Strain ZGt-1: Production, Proteomics, and Bioinformatics Analysis. Int J Mol Cell Med 17: 1363.

12. Abdel-Fattah YR, Saeed HM, Gohar YM, El-Baz MA (2005) Improved production of Pseudomonas aeruginosa uricase by optimization of process parameters through statistical experimental designs. Process Biochem 40: 1707-1714.

13. Wang ZW, Liu XL (2008) Medium optimization for antifungal active substances production from a newly isolated Paenibacillus sp. using response surface methodology. Bioresour Technol 99: 8245-8251.

14. Biswas SR, Ray P, Johnson MC, Ray B (1991) Influence of growth conditions on the production of a bacteriocin, Pediocin AcH by Pediococcus acidilactici H. Appl Environ Microbiol 57: 1265-1267.

15. Nel HA, Bauer R, Vandamme EJ, Dicks LMT (2001) Growth optimization of Pediococcus damnosus NCFB 1832 and the influence of $\mathrm{pH}$ and nutrients on the production of pediocin PD-1. J Appl Microbiol 91: 1131-1138.

16. Herranz C, Martınez JM, Rodrıguez JM, Hernandez PE, Cintas LM (2001) Optimization of Enterocin P production by batch fermentation of Enterococcus faecium P13 at Constant pH. Appl Microbiol Biotechnol 56: 378-383.

17. De Vuyst L, Vandamme EJ (1992) Influence of the carbon source on nisin production in Lactococcus lactis subsp. lactis batch fermentations. J Gen Microbiol 138: 571-578.

18. Verellen TLJ, Bruggeman G, Van Reenen CA, Dicks LMT, Vandamme EJ (1998) Fermentation optimization of Plantaricin 423, a bacteriocin produced by Lactobacillus plantarum 423. J Ferment Bioeng 86: 174-179.

19. Aasen IM, Moreto T, Katla T, Axelsson L, Storro I (2000) Influence of complex nutrients, temperature and $\mathrm{pH}$ on bacteriocins production by Lactobacillus sakei CCUG 42687. Appl Microbiol Biotechnol 53: 159-166.

20. Abo-Amer AE (2011) Optimization of bacteriocin production by Lactobacillus acidophilus AA11, a strain isolated from Egyptian cheese. Ann Microbiol 61: 445-452.

21. Lee YM, Kim JS, Kim WJ (2012) Optimization for the maximum bacteriocin production of Lactobacillus brevis DF01 using response surface methodology. Food Sci Biotechnol 21: 653-659.

22. Mezghanni H, Khedher S, Tounsi S, Zouari N (2012) Medium optimization of antifungal activity production by Bacillus amyloliquefaciens using statistical experimental design. Prep Biochem Biotechnol 42: 267-278.

23. Zhang X, Chang X, Liu G, Wu P, Li P (2012) A newly anti-streptococcus suis bacteriocin producing strain from unweaned piglets fecal matter: 
Citation: Kaunietis A, Pranckute R, Lastauskiene E, Citavicius DJ (2017) Medium Optimization for Bacteriocin Production and Bacterial Cell Growth of Geobacillus sp. 15 Strain. J Antimicrob Agents 3: 133. doi:10.4172/2472-1212.1000133

Page 5 of 5

isolation, preliminary identification, and optimization of medium composition for enhanced bacteriocin production. Prep Biochem Biotechnol 42: 393-405.

24. Mortverd-Abildgaard CI, Nissen-Meyer J, Jelle B, Grenov B, Skaugen M, et al. (1995) Production and $\mathrm{pH}$-dependent bacteriocidal activity of lactocin S, a lantibiotic from Lactobacillus sake L45. Appl Environ Microbiol 61: 175-179.

25. De Vuyst L, Callewaert R, Crabbe K (1996) Primary metabolite kinetics of bacteriocin biosynthesis by Lactobacillus amylovorus and evidence for stimulation of bacteriocin production under unfavourable growth conditions. Microbiology 142: 817-827.

26. Kim WS, Hall RJ, Dunn NW (1997) The effect of nisin concentration and nutrient depletion on nisin production of Lactococcus lactis. Appl Microbiol Biotechnol 50: 429-433.

27. Callewaert R, De Vuyst L (2000) Bacteriocin production with Lactobacillus amylovorus DCE 471 is improved and stabilized by fedbatch fermentation. Appl Environ Microbiol 66: 606-613.
28. Bogovic-Matijasic B, Rogelj I (1998) Bacteriocin complex of Lactobacillus acidophilus LF221-production studies in MRS media at different $\mathrm{pH}$ values and effect against Lactobacillus helveticus ATCC 15009. Process Biochem 33: 345-352.

29. Parente E, Ricciardi A (1994) Influence of $\mathrm{pH}$ on the production of enterocin 1146 during batch fermentation. Lett Appl Microbiol 19: 12-15.

30. Matsusaki H, Endo N, Sonomoto K, Ishizaki A (1996) Lantibiotic nisin Z fermentative production by Lactococcus lactis IO-1: relationship between production of the lantibiotic and lactate and cell growth. Appl Microbiol Biotechnol 45: 36-40.

31. Krier F, Revol-Junelles AM, Germain P (1998) Influence of temperature and $\mathrm{pH}$ on production of two bacteriocins by Leuconostoc mesenteroides subsp. mesenteroides FR52 during batch fermentation. Appl Microbiol Biotechnol 50: 359-363.

32. Todorov S, Gotcheva B, Dousset X, Onno B, Ivanova I (2000) Influence of growth medium on bacteriocin production in Lactobacillus plantarum ST31. Biotechnol Biotechnol Equip 1: 50-55. 